\title{
Sexual Differentiation of the Bed Nucleus of the Stria Terminalis in Humans May Extend into Adulthood
}

\author{
Wilson C. J. Chung, ${ }^{1,2}$ Geert J. De Vries, ${ }^{2}$ and Dick F. Swaab ${ }^{1}$ \\ ${ }^{1}$ Netherlands Institute for Brain Research, 1105 AZ Amsterdam, The Netherlands, and ${ }^{2}$ Center for Neuroendocrine \\ Studies and Department of Psychology, University of Massachusetts, Amherst, Massachusetts 01003
}

\begin{abstract}
Gonadal steroids have remarkable developmental effects on sex-dependent brain organization and behavior in animals. Presumably, fetal or neonatal gonadal steroids are also responsible for sexual differentiation of the human brain. A limbic structure of special interest in this regard is the sexually dimorphic central subdivision of the bed nucleus of the stria terminalis (BSTc), because its size has been related to the gender identity disorder transsexuality. To determine at what age the BSTc becomes sexually dimorphic, the BSTc volume in males and females was studied from midgestation into adulthood. Using vasoactive
\end{abstract}

intestinal polypeptide and somatostatin immunocytochemical staining as markers, we found that the BSTc was larger and contains more neurons in men than in women. However, this difference became significant only in adulthood, showing that sexual differentiation of the human brain may extend into the adulthood. The unexpectedly late sexual differentiation of the BSTc is discussed in relation to sex differences in developmental, adolescent, and adult gonadal steroid levels.

Key words: bed nucleus of stria terminalis; sexual differentiation; plasticity; brain; adulthood; human
Several regions in the human brain differ in organization between men and women. For example, distinct cell groups in the preoptic and anterior hypothalamic area are larger, and the suprachiasmatic nucleus contains more vasoactive intestinal polypeptideimmunoreactive (VIP-IR) cells in young men than in young women (Swaab and Fliers, 1985; Allen et al., 1989; LeVay, 1991; Swaab et al., 1994; Byne et al., 2000). Clear anatomical sex differences have also been described in the human bed nucleus of the stria terminalis (BST). The darkly staining posteromedial component of the BST (BST-dspm) and the central subdivision of the BST (BSTc) are both larger in men than in women (Allen and Gorski, 1990; Zhou et al., 1995; Kruijver et al., 2000). Differences in the size of the human BSTc have been related to the gender identity disorder transsexuality, in which subjects voice the strong feeling of being born in the wrong sex. In male-to-female transsexuals, the BSTc was similar in size to that of control women, whereas in the only female-to-male transsexual studied so far, the BSTc was similar in size to that of control men (Swaab and Hofman, 1995; Zhou et al., 1995; Kruijver et al., 2000)

In general, perinatal sex differences in gonadal steroid levels are responsible for organizing the vertebrate brain in a sexdependent manner (Döhler, 1991; Cooke et al., 1998). Studies showed that this was also the case for the sexual differentiation of the BST in the rat brain. For instance, perinatal sex differences in testosterone are required for the principal nucleus of the BST in the rat brain to become larger and contain more cells in males than in females (Del Abril et al., 1987; Guillamon et al., 1988;

Received July 24, 2001; revised Oct. 2, 2001; accepted Oct. 29, 2001.

This research was supported by the Royal Netherlands Academy for Arts and Sciences (Ter Meulen Fonds) to W.C.J.C. We thank B. Fisser, J. J. van Heerikhuize, and U. A. Unmehopa for their technical assistance and M. A. Hofman for his comments. Brain material was collected by the Netherlands Brain Bank (coordinator R. Ravid).

Correspondence should be addressed to Wilson C. J. Chung, Netherlands Institute for Brain Research, Meibergdreef 33, 1105 AZ Amsterdam, The Netherlands. E-mail: w.chung@nih.knaw.nl.

Copyright (C) 2002 Society for Neuroscience $\quad 0270-6474 / 02 / 221027-07 \$ 15.00 / 0$
Chung et al., 2000). Moreover, these sex-dependent morphological changes occur within the first week of postnatal life (Chung et al., 2000). Therefore, gonadal steroids are presumed to play a role in the sexual differentiation of the human BSTc, which was predicted to be apparent early on during fetal or infant development. This idea is further supported by observations in humans, which indicate that dramatic changes in circulating gonadal steroid levels do not seem to alter the size of the BSTc in adult control subjects. For instance, high testosterone and androstenedione levels caused by an adrenal cortex tumor in a female control subject did not result in a larger BSTc, whereas gonadectomy in male control subjects with prostate cancer did not result in a smaller BSTc (Zhou et al., 1995; Kruijver et al., 2000).

In the present study, we used postmortem human brain tissue to determine at what stage of development the volume of the human BSTc diverges between men and women. Moreover, we assessed whether sex differences in total number of Nissl-stained BSTc neurons contributed to the sexual differentiation of the BSTc size.

\section{MATERIALS AND METHODS}

Human brain tissue. Brains of 50 control subjects (Table 1) were obtained through autopsies by the Netherlands Brain Bank following the required permissions for brain autopsy and use of tissue and medical information for research purposes. Brain tissue was fixed in formalin and embedded in paraffin. Serial coronal sections $(6 \mu \mathrm{m})$ were made using a Leitz (Wetzlar, Germany) microtome and mounted on aminoalkylsilanecoated glass slides. Paraffin-embedded sections were processed for immunocytochemistry as described in previous studies (Zhou et al., 1995; Kruijver et al., 2000).

Immunocytochemistry. After deparaffinization and rehydration using xylene and decreasing grades of ethanol, sections were placed in $0.05 \mathrm{M}$ citrate buffer, $\mathrm{pH} 4.0$, microwave treated (for antigen retrieval) at $90^{\circ} \mathrm{C}$ for $10 \mathrm{~min}$, cooled at room temperature (RT) for $30 \mathrm{~min}$, rinsed three times for $5 \mathrm{~min}$ each in $0.05 \mathrm{~m}$ Tris-buffered saline (TBS), pH 7.6, and placed into $0.3 \%$ Triton X-100 (Sigma, St. Louis, MO) and 5\% milk powder (Elk; Campina Melkunie, Eindhoven, The Netherlands) diluted with TBS (TBS-XM) for $30 \mathrm{~min}$ to reduce nonspecific staining. Sections were then incubated overnight at $4^{\circ} \mathrm{C}$ with rabbit anti-VIP polyclonal (VIPER; 1:600) or rabbit anti-somatostatin polyclonal (SOMAAR; 
Table 1. Control human brain material

\begin{tabular}{|c|c|c|c|c|c|c|c|c|c|}
\hline & NBB number & Sex & Age & $\begin{array}{l}\text { Brain weight } \\
(\mathrm{gm})\end{array}$ & $\begin{array}{l}\text { Postmortem } \\
\text { delay (hr) }\end{array}$ & $\begin{array}{l}\text { Fixation } \\
\text { (d) }\end{array}$ & $\begin{array}{l}\mathrm{VIP} \\
\left(\mathrm{mm}^{3}\right)\end{array}$ & $\begin{array}{l}\mathrm{SOM} \\
\left(\mathrm{mm}^{3}\right)\end{array}$ & $\begin{array}{l}\text { Clinicopathological } \\
\text { diagnosis }\end{array}$ \\
\hline \multirow[t]{28}{*}{ Males $(n=25)$} & Fetal/neonatal period & & & & & & & & \\
\hline & 81024 & $\mathrm{~m}$ & $264 / 7$ weeks & 110 & $1: 52$ & 51 & 0.216 & 0.376 & Pulmonary failure \\
\hline & 84032 & $\mathrm{~m}$ & 27 weeks & 142 & $21: 45$ & 45 & 0.241 & 0.462 & Cardiac failure \\
\hline & 97154 & $\mathrm{~m}$ & 33 6/7 weeks & 186 & $7: 55$ & 32 & 0.729 & 1.136 & $\begin{array}{l}\text { Respiratory insuffi- } \\
\text { ciency }\end{array}$ \\
\hline & 82002 & $\mathrm{~m}$ & $351 / 7$ weeks & 322 & $<41: 00$ & 32 & 0.766 & 1.088 & Pericardial rupture \\
\hline & 94054 & $\mathrm{~m}$ & $362 / 7$ weeks & 357 & $<24: 00$ & 118 & 0.703 & 1.238 & $\begin{array}{l}\text { Pulmonalis atresia, } \\
\text { cardiac insufficiency }\end{array}$ \\
\hline & 90095 & $\mathrm{~m}$ & $381 / 7$ weeks & 320 & $14: 05$ & 26 & 0.624 & 1.018 & $\begin{array}{l}\text { Respiratory insuffi- } \\
\text { ciency }\end{array}$ \\
\hline & 88120 & $\mathrm{~m}$ & 40 weeks & 440 & $<17: 00$ & 31 & 1.284 & 2.125 & Asphyxia \\
\hline & Infant/pubertal period & & & & & & & & \\
\hline & 88053 & $\mathrm{~m}$ & 3 months & 485 & $<41: 00$ & 35 & 1.445 & 2.520 & $\begin{array}{l}\text { Pulmonal insuffi- } \\
\text { ciency, Fallot's te- } \\
\text { tralogy }\end{array}$ \\
\hline & 85036 & $\mathrm{~m}$ & 3 months & 635 & $<17: 00$ & 73 & 1.583 & 2.582 & $\begin{array}{l}\text { Cardiac failure, aortic } \\
\text { stenosis, cerebral } \\
\text { ischemia }\end{array}$ \\
\hline & 84019 & $\mathrm{~m}$ & 3 months & 710 & $<11: 00$ & 792 & 1.034 & 2.318 & $\begin{array}{l}\text { Sudden infant death } \\
\text { syndrome }\end{array}$ \\
\hline & 86041 & $\mathrm{~m}$ & 6 months & 800 & $<6: 30$ & 14 & 1.515 & 2.663 & $\begin{array}{l}\text { Sudden infant death } \\
\text { syndrome }\end{array}$ \\
\hline & 88092 & $\mathrm{~m}$ & 1 year & 920 & $<41: 00$ & 31 & 2.587 & 4.536 & $\begin{array}{l}\text { Penthotal intoxica- } \\
\text { tion, hypoxia }\end{array}$ \\
\hline & 88058 & $\mathrm{~m}$ & 1 year & 1070 & $<35: 35$ & 28 & 2.597 & 3.843 & $\begin{array}{l}\text { Bacterial meningitis, } \\
\text { sepsis }\end{array}$ \\
\hline & 84016 & $\mathrm{~m}$ & 5 years & 1565 & $23: 55$ & 100 & 2.083 & 3.074 & Sepsis \\
\hline & 87057 & $\mathrm{~m}$ & 6 years & 1550 & $3: 30$ & 41 & 3.836 & 5.637 & Peritonitis \\
\hline & 98116 & $\mathrm{~m}$ & 8 years & nd & $<17: 10$ & 103 & 2.826 & 5.595 & Cardiomyopathy \\
\hline & 87036 & $\mathrm{~m}$ & 14 years & 1640 & $<41: 00$ & 32 & 4.968 & 8.059 & Lymphadenopathy \\
\hline & Adult period & & & & & & & & \\
\hline & 97083 & $\mathrm{~m}$ & 22 years & 1334 & $<16: 29$ & 26 & 4.067 & 5.897 & Cardiomyopathy \\
\hline & 97173 & $\mathrm{~m}$ & 24 years & 1364 & $<33: 30$ & 31 & 3.969 & 6.708 & Accidental death \\
\hline & 86042 & $\mathrm{~m}$ & 28 years & 1450 & $<17: 00$ & 46 & 3.618 & 5.254 & $\begin{array}{l}\text { Guillain-Barré syn- } \\
\text { drome }\end{array}$ \\
\hline & 96406 & $\mathrm{~m}$ & 35 years & 1430 & $13: 30$ & 1214 & 3.288 & 6.598 & $\begin{array}{l}\text { Pulmonary aspergillo- } \\
\text { sis }\end{array}$ \\
\hline & 99071 & $\mathrm{~m}$ & 39 years & 1400 & $<16: 30$ & 130 & 3.362 & 6.919 & Cardiac failure \\
\hline & 88011 & $\mathrm{~m}$ & 41 years & 1500 & $20: 30$ & 33 & 4.464 & 6.745 & Suicide \\
\hline & 92011 & $\mathrm{~m}$ & 47 years & 1500 & $<89: 00$ & 77 & 4.258 & 4.915 & Sepsis \\
\hline & 97159 & $\mathrm{~m}$ & 48 years & 1500 & $5: 30$ & 42 & 3.757 & 5.948 & $\begin{array}{l}\text { Diabetes mellitus } \\
\text { type I, euthanasia }\end{array}$ \\
\hline \multirow[t]{7}{*}{ Females $(n=25)$} & Fetal/neonatal period & & & & & & & & \\
\hline & 89056 & $\mathrm{f}$ & $256 / 7$ weeks & 100 & $<65: 00$ & 31 & 0.362 & 0.579 & $\begin{array}{l}\text { Idiopathic (infant) } \\
\text { respiratory distress } \\
\text { syndrome }\end{array}$ \\
\hline & 96401 & $\mathrm{f}$ & 27 2/7 weeks & 77 & $<41: 00$ & 1301 & 0.217 & 0.460 & Congenital infection \\
\hline & 98193 & $\mathrm{f}$ & $306 / 7$ weeks & 116 & $3: 00$ & 82 & 0.579 & 1.023 & Sepsis \\
\hline & 86030 & $\mathrm{f}$ & 31 2/7 weeks & 200 & $<41: 00$ & 33 & 1.011 & 1.545 & Hypoxia \\
\hline & 87024 & $\mathrm{f}$ & $345 / 7$ weeks & 180 & $<3: 15$ & 38 & 0.368 & 0.770 & $\begin{array}{l}\text { Idiopathic (infant) } \\
\text { respiratory distress } \\
\text { syndrome }\end{array}$ \\
\hline & 96403 & $\mathrm{f}$ & 34 4/7 weeks & 197 & $<57: 19$ & 1288 & 0.385 & 0.951 & $\begin{array}{l}\text { Developmental syn- } \\
\text { drome }\end{array}$ \\
\hline
\end{tabular}




\begin{tabular}{|c|c|c|c|c|c|c|c|c|}
\hline NBB number & Sex & Age & $\begin{array}{l}\text { Brain weight } \\
(\mathrm{gm})\end{array}$ & $\begin{array}{l}\text { Postmor- } \\
\text { tem delay } \\
\text { (hr) }\end{array}$ & $\begin{array}{l}\text { Fixation } \\
\text { (d) }\end{array}$ & $\begin{array}{l}\text { VIP } \\
\left(\mathrm{mm}^{3}\right)\end{array}$ & $\begin{array}{l}\mathrm{SOM} \\
\left(\mathrm{mm}^{3}\right)\end{array}$ & $\begin{array}{l}\text { Clinicopathological } \\
\text { diagnosis }\end{array}$ \\
\hline 88123 & $\mathrm{f}$ & 37 6/7 weeks & 350 & $<41: 00$ & 30 & 1.067 & 2.544 & Cardiac failure \\
\hline 89092 & $\mathrm{f}$ & $401 / 7$ weeks & 380 & $30: 45$ & 28 & 0.696 & 1.066 & Asphyxia \\
\hline 88077 & $\mathrm{f}$ & 40 2/7 weeks & 350 & $<65: 00$ & 56 & 0.782 & 1.378 & Asphyxia \\
\hline 87028 & $\mathrm{f}$ & 41 4/7 weeks & 350 & $<41: 00$ & 33 & 0.880 & 2.444 & Aspiration of maternal blood \\
\hline \multicolumn{9}{|c|}{ Infant/pubertal period } \\
\hline 86027 & $\mathrm{f}$ & 5 months & 735 & $10: 00$ & 40 & 1.028 & 1.890 & Sudden infant death syndrome \\
\hline 89027 & $\mathrm{f}$ & 6 months & 780 & $<17: 00$ & 28 & 1.033 & 2.890 & Cardiomyopathy \\
\hline 89036 & $\mathrm{f}$ & 1 year & 820 & nd & 31 & 2.366 & 3.956 & Hypoglycaemia \\
\hline 85031 & $\mathrm{f}$ & 2 years & nd & $<65: 00$ & 48 & 1.028 & 4.699 & Kidney dysplasia, sepsis \\
\hline 87077 & $\mathrm{f}$ & 7 years & 1320 & $<9: 45$ & 33 & 1.033 & 5.287 & Astrocytoma \\
\hline 87035 & $\mathrm{f}$ & 13 years & 1250 & $<13: 00$ & 48 & 2.366 & 7.243 & $\begin{array}{l}\text { Histiocystic lymphoma, car- } \\
\text { diac failure }\end{array}$ \\
\hline 99060 & $\mathrm{f}$ & 16 years & 1364 & $<43: 00$ & 238 & 3.251 & 6.662 & Diabetes mellitus, acidosis \\
\hline \multicolumn{9}{|l|}{ Adult period } \\
\hline 85041 & $\mathrm{f}$ & 28 years & nd & $5: 25$ & 44 & 3.218 & 6.384 & Cardiac failure \\
\hline 85027 & $\mathrm{f}$ & 29 years & 1150 & $13: 10$ & 60 & 4.318 & 3.131 & Coma, liver cirrhosis \\
\hline 92037 & $\mathrm{f}$ & 32 years & 1280 & $30: 00$ & 45 & 3.518 & 3.334 & Bronchitis, pneumonia \\
\hline 86032 & $\mathrm{f}$ & 33 years & 1035 & $<41: 00$ & 20 & 2.411 & 4.179 & Adenocarcinoma \\
\hline 84002 & $\mathrm{f}$ & 36 years & 1420 & $85: 40$ & 51 & 1.893 & 3.688 & $\begin{array}{l}\text { Suicide, multiple fractures, } \\
\text { aortic rupture }\end{array}$ \\
\hline 97131 & $\mathrm{f}$ & 43 years & 1345 & $<92: 00$ & 63 & 2.293 & 3.647 & $\begin{array}{l}\text { Cardiac failure, liver cirrho- } \\
\text { sis }\end{array}$ \\
\hline 89104 & $\mathrm{f}$ & 49 years & 1260 & $<41: 00$ & 32 & 3.877 & 6.512 & Lung carcinoma, septic shock \\
\hline 96423 & $\mathrm{f}$ & 49 years & 1253 & $<17: 00$ & 806 & 3.183 & 5.316 & $\begin{array}{l}\text { Adenocarcinoma, thrombo- } \\
\text { embolism }\end{array}$ \\
\hline
\end{tabular}

M, Male; F, female; nd, not determined; NBB, Netherlands Brain Bank; SOM, somatostatin.

1:800) diluted in TBS-XM. Afterward, sections were rinsed one time for $5 \mathrm{~min}$ in TBS-XM and two times for $5 \mathrm{~min}$ each in TBS and incubated with biotinylated goat anti-rabbit (1:300; Vector Laboratories, Burlingame, CA) diluted in TBS-XM for $60 \mathrm{~min}$ at RT. Sections were rinsed three times for 5 min each in TBS and incubated with ABC Elite kit (1:600; Vector Laboratories) diluted in TBS for $60 \mathrm{~min}$ and, after an additional three rinses for $5 \mathrm{~min}$ each in TBS, reacted with $0.25 \%$ nickel-ammonium sulfate-enhanced 3,3' diaminobenzidine tetrahydrochloride $(0.5 \mathrm{mg} / \mathrm{ml})$ and $0.01 \% \mathrm{H}_{2} \mathrm{O}_{2}$ in TBS. The reaction was stopped after 10-20 min, dehydrated with increasing grades of ethanol, cleared with xylene, and coverslipped using entellan (Merck, Darmstadt, Germany).

Volume measurements. The volume of the human BSTc in control subjects (males, $n=25$; females, $n=25$ ) was assessed both by using VIP and somatostatin immunocytochemical staining as markers (Walter et al., 1991; Zhou et al., 1995; Kruijver et al., 2000). Both markers have been shown previously to delineate clearly the borders of the BSTc in adult males and females (Zhou et al., 1995; Kruijver et al., 2000). The present study showed that the same markers delineate the BSTc from 25 weeks of pregnancy onward (Table 1). The volume of the BSTc was estimated by measuring the cross-sectional area delineated by VIP or somatostatin immunoreactivity in approximately every 25 th section (fetal/neonatal and infant/pubertal subjects) or every 50th section (adult subjects) using a $2.5 \times$ objective (Plan-Neofluar) on a Zeiss (Oberkochen, Germany) Axioskop microscope mounted with a Sony (Tokyo, Japan) B/W CCD camera (model XC77CE) connected to an IBAS imaging analysis system (Kontron Elektronik, Eching, Germany). The total volume of the BSTc was calculated according to the Cavalieri principle (Gundersen et al., 1988).

Estimation of neuronal density and total neuronal number. Somatostatin-stained sections of the BSTc from adult males and females (between 22 and 49 years) (Table 2) were counterstained with Nissl staining to reveal all cells and to estimate total neuronal number in the adult BSTc. Cross-sectional digital images (every 50th to 100th section) were made using a $2.5 \times$ objective (Plan-Neofluar) on a Zeiss Axioskop microscope, mounted with a Sony B/W CCD camera (model XC77CE), that was connected to an IBAS imaging analysis system (Kontron Elektronik). The somatostatin-stained BSTc was outlined at $2.5 \times$ magnification; subsequently, the imaging analysis system overlaid a grid of rectangular fields within the outlined cross-sectional area. Each field was equal in size to the area displayed by the camera at $63 \times$ objective (Plan-Apochromat). For analysis, 25\% of the rectangular fields (each field covering at least $10 \%$ of the outlined area) was selected by a random systematic sampling procedure. To prevent double counting, only neurons containing a nucleolus $(\sim 2 \mu \mathrm{m}$ diameter $)$ were counted. This counting procedure is first based on the assumption that the cell nucleus only contains one nucleolus. No multi-nucleolated nuclei were observed in our sections, confirming the observation of Kruijver et al. (2000) for the BSTc. Second, nucleoli are considered to be hard particles that will not be sectioned by a microtome knife but instead are pushed either in or out the paraffin when hit by a microtome knife (Jones, 1937; Cammermeyer, 1967; Koningsmark, 1970; Braendgaard and Gundersen, 1986). All visible neurons with a nucleus containing a clear nucleolus, within the exclusion lines, were counted using a $63 \times$ objective. The neuronal density was calculated by multiplying the total number of nucleoli counted by the sampled volume. The total number of neurons was then estimated for the adult BSTc by multiplying neuronal density with the total BSTc volume. The measurements were made without knowledge of age and sex.

Statistical analysis. The data were categorized in a fetal/neonatal period (between the 25th and 41th weeks of gestation), an infant/ pubertal period (between 3 months and 16 years), and an adult period (between 22 and 49 years) and were tested for significant differences using one-way ANOVA and $t$ tests (see Fig. 2). A $p<0.05$ was considered as significant.

\section{RESULTS}

BSTc volume defined by VIP immunostaining was $\sim 60.7 \pm 3.1 \%$ (SEM) smaller than BSTc volume defined by somatostatin immunostaining across all age groups (Figs. 1, 2) because of the 
Table 2. Total number of neurons in the BSTc

\begin{tabular}{|c|c|c|c|c|c|c|c|c|}
\hline & NBB & Sex & $\begin{array}{l}\text { Age } \\
\text { (years) }\end{array}$ & $\begin{array}{l}\text { Brain } \\
\text { weight } \\
\text { (gm) }\end{array}$ & $\begin{array}{l}\text { Postmortem } \\
\text { delay (hr) }\end{array}$ & $\begin{array}{l}\text { Fixation } \\
\text { (d) }\end{array}$ & $\begin{array}{l}\text { Neuronal } \\
\text { density } \\
\left(\mathrm{mm}^{3}\right)\end{array}$ & $\begin{array}{l}\text { Total number of } \\
\text { BSTc neurons }\end{array}$ \\
\hline \multirow[t]{8}{*}{ Males $(n=8)$} & 97083 & $\mathrm{~m}$ & 22 & 1334 & $<16: 29$ & 26 & 12930 & 76249 \\
\hline & 97173 & $\mathrm{~m}$ & 24 & 1364 & $<33: 30$ & 31 & 17012 & 114120 \\
\hline & 86042 & $\mathrm{~m}$ & 28 & 1450 & $<17: 00$ & 46 & 18240 & 96200 \\
\hline & 96406 & $\mathrm{~m}$ & 35 & 1430 & $13: 30$ & 1214 & 18095 & 119383 \\
\hline & 99071 & $\mathrm{~m}$ & 39 & 1400 & $<16: 30$ & 130 & 16346 & 113095 \\
\hline & 88011 & $\mathrm{~m}$ & 41 & 1500 & $20: 30$ & 33 & 15158 & 102247 \\
\hline & 92011 & $\mathrm{~m}$ & 47 & 1500 & $<89: 00$ & 77 & 18267 & 89782 \\
\hline & 97159 & $\mathrm{~m}$ & 48 & 1500 & $5: 30$ & 42 & 15070 & 89630 \\
\hline \multirow[t]{7}{*}{ Females $(n=7)$} & 85041 & $\mathrm{f}$ & 28 & nd & $5: 25$ & 44 & 16255 & 103774 \\
\hline & 85027 & $\mathrm{f}$ & 29 & 1150 & $13: 10$ & 60 & 19597 & 61353 \\
\hline & 86032 & $\mathrm{f}$ & 33 & 1035 & $<41: 00$ & 20 & 19541 & 81669 \\
\hline & 84002 & $\mathrm{f}$ & 36 & 1420 & $85: 40$ & 51 & 20204 & 74509 \\
\hline & 97131 & $\mathrm{f}$ & 43 & 1345 & $<92: 00$ & 63 & 20639 & 75268 \\
\hline & 89104 & $\mathrm{f}$ & 49 & 1260 & $<41: 00$ & 32 & 13552 & 88245 \\
\hline & 96423 & $\mathrm{f}$ & 49 & 1253 & $<17: 00$ & 806 & 17443 & 92717 \\
\hline
\end{tabular}

NBB, Netherlands Brain Bank; F, female; M, male; SOM, somatostatin.

Figure 1. Representative photomicrographs depicting the BSTc in males (top row) and females (bottom row) in sections stained immunocytochemically for VIP $(A, C, E, G)$ and somatostatin (SOM) $(B, D, F, G)$ during development. $A, B, \# 87036,14$ years old; $C, D$, \#99071, 39 years old; $E, F$, \#99060, 16 years old; $G, H$, \#92037, 32 years old. Note that the BSTc in males is larger than in females only in adulthood (\#99071 vs \#92037). Scale bar, $1 \mathrm{~mm}$. $a c$, Anterior commissure; ic, internal capsule; $l v$, lateral ventricle.
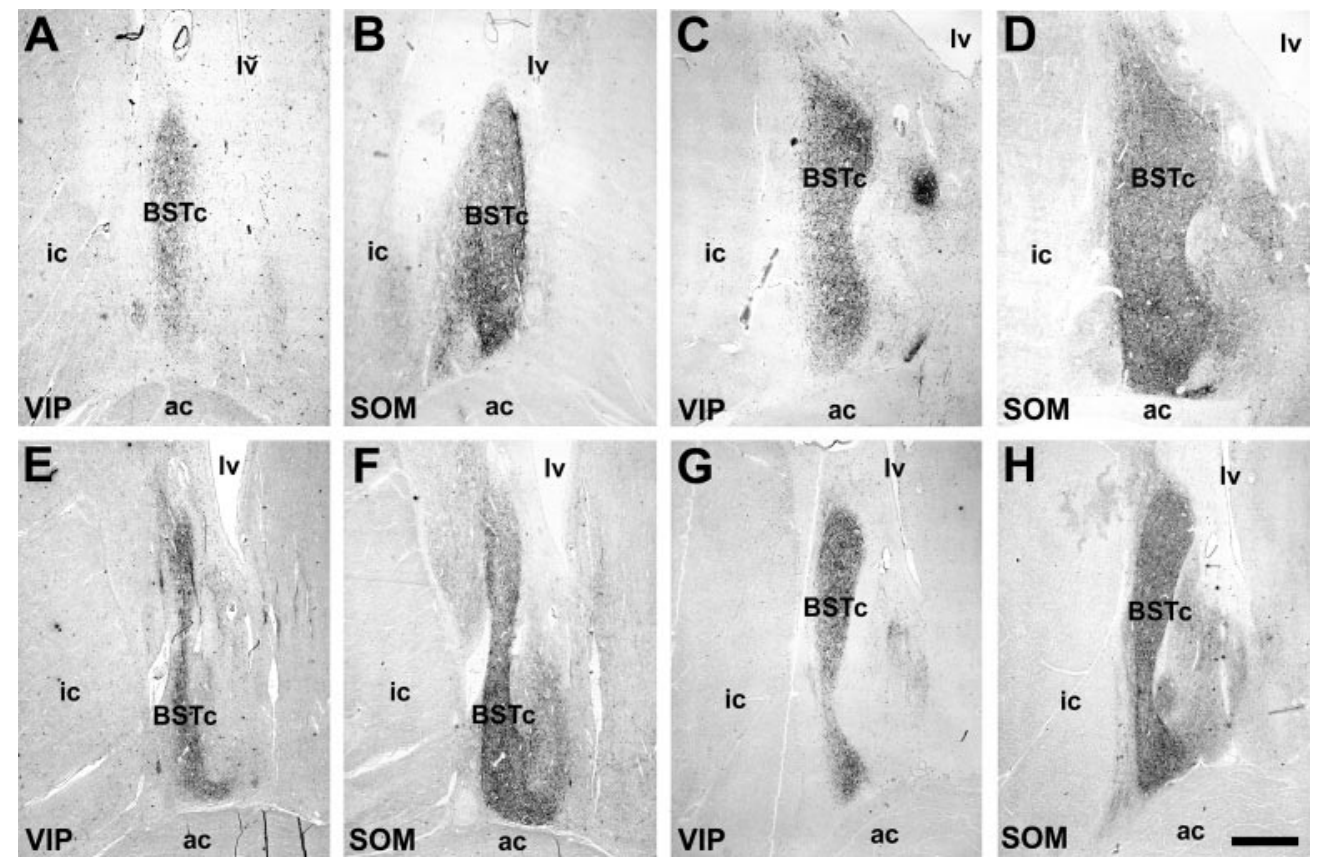

presence of somatostatin-IR fibers in the cell-sparse shell that surrounds the VIP-IR fibers in the BSTc core. No postmortem delay or fixation time effects on the immunocytochemical staining were observed. Regression analysis showed that BSTc volume in both males and females defined by VIP immunocytochemistry is correlated with BSTc volume defined by somatostatin immunocytochemistry (in males, $r=0.96, p<0.0001$; in females $r=0.73$, $p<0.0001$ ) (Fig. 2).

One-way ANOVA showed that the male BSTc volume significantly increased with age as based on its VIP $\left(F_{(2,24)}=27.4 ; p<\right.$ $0.0001)$ or somatostatin $\left(F_{(2,23)}=28.2 ; p<0.0001\right)$ immunocytochemical staining. Post hoc analysis showed that the fetal/neonatal, infant/pubertal, and adult age groups significantly differed from each other $(p<0.05)$. The female BSTc volume significantly increased with age as based on its VIP staining $\left(F_{(2,24)}=22.2 ; p<\right.$
$0.0001)$ or somatostatin staining $\left(F_{(2,23)}=18.1 ; p<0.0001\right)$. Post $h o c$ analysis showed that only the fetal/neonatal-infant/pubertal age groups and the fetal/neonatal-adult age groups $(p<0.05)$, but not the infant/pubertal-adult age group, significantly differed from each other (Fig. $2 A, B$ ). Consequently, adult BSTc volume was on average $39 \%$ larger in males than in females $(t=2.14, p<0.001$ for VIP; $t=2.14, p<0.01$ for somatostatin; $t$ test), thereby confirming previous studies, which showed that the adult BSTc size is larger in males than in females (Zhou et al., 1995; Kruijver et al., 2000) (Fig. $2 C, D)$. Moreover, the total number of BSTc neurons in adulthood (i.e., between 22 and 49 years) was significantly $(t=2.16 ; p<0.05)$ larger in males $(100,088 \pm 5247)$ than in females $(82,505 \pm 5242)$ (Fig. 2E), which is consistent with the larger number of somatostatin-IR neurons found in males compared with females in adulthood (Kruijver et al., 2000). 

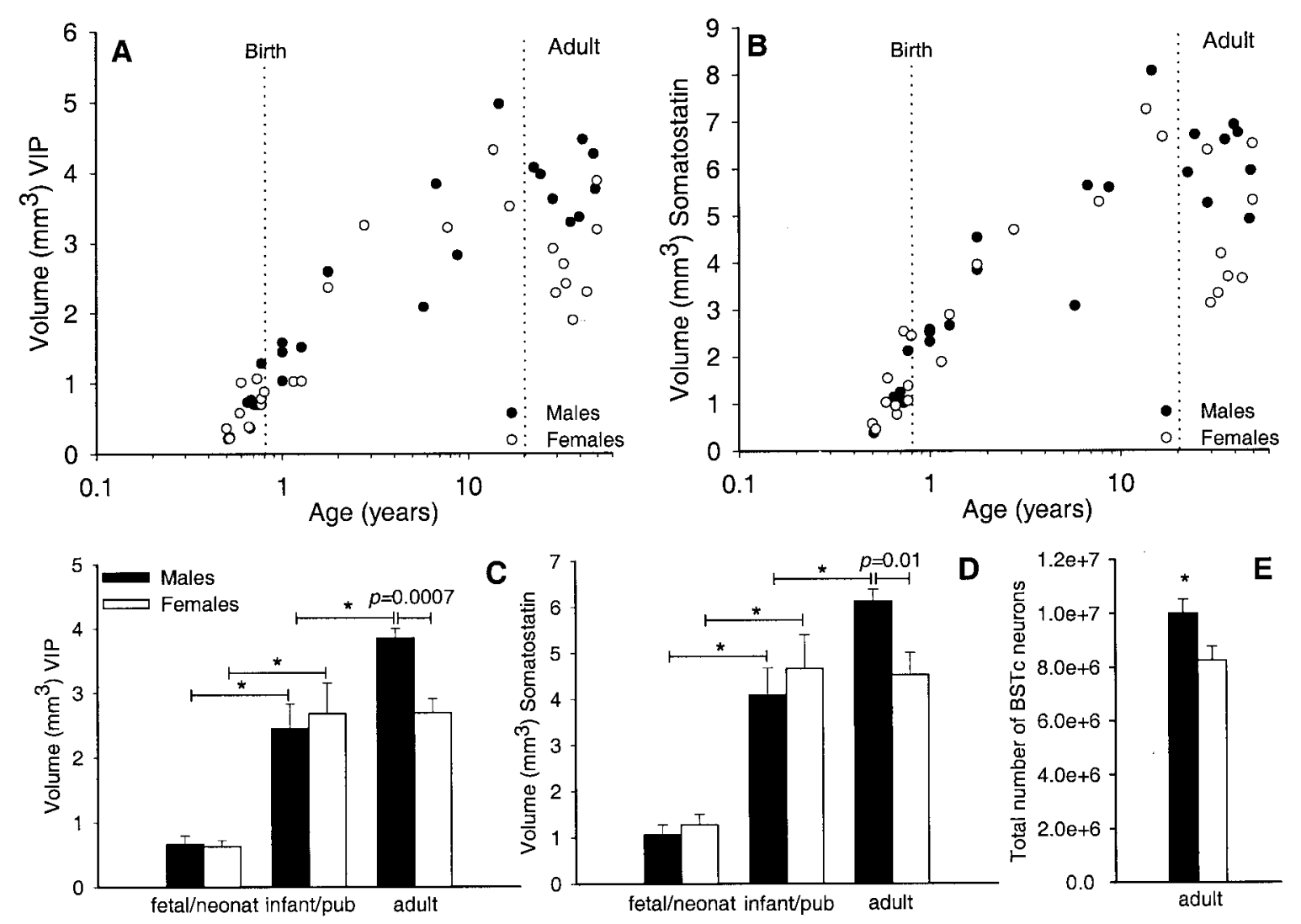

Figure 2. BSTc development in males and females. $A, C$, BSTc volume as delineated by its VIP innervation. $B, D$, BSTc volume as delineated by its somatostatin innervation. $E$, Total number of BSTc neurons in males and females in adulthood.

\section{DISCUSSION}

The sex difference in BSTc volume, which reached significance only in adulthood, developed much later than we expected. Sexual differentiation of the rat BST occurs in the first weeks after birth and requires perinatal sex differences in testosterone levels (Del Abril et al., 1987; Chung et al., 2000). In humans, testosterone levels during fetal and neonatal development are higher in males than in females (Abramovich and Rowe, 1973; Winter, 1978). In addition, dramatic alterations in adult testosterone levels have no obvious effects on the volume of the BSTc in either males or females (Zhou et al., 1995; Kruijver et al., 2000). Therefore, the BSTc was presumed to diverge between males and females early on in development. Moreover, sexual differentiation of the sexually dimorphic nucleus of the preoptic area and other areas in the human anterior hypothalamus occurs between 4 and 10 years of age (Swaab and Hofman, 1988; Swaab et al., 1994).

The late divergence of BSTc volume in males and females may be a general characteristic of the human BST. The human BSTdspm seems to become sexually dimorphic at approximately puberty, as suggested by the developmental time points that were included in the study by Allen and Gorski (1990). Indeed, the BST-dspm appeared to be smaller in females than in males from $\sim 14$ years of age (Allen and Gorski, 1990). Relatively late sexual differentiation has also been observed in the pig hypothalamus. The number of cells in the sexually dimorphic vasopressin and oxytocin-containing nucleus in the pig hypothalamus increases in (post)adolescent females but not in males (Van Eerdenburg and Swaab, 1994). Recent studies also showed that several regions in the adult human and primate brain continuously produce new neurons and change in gray and white matter volume (Eriksson et al., 1998; Gould et al., 1999; Gur et al., 1999; Sowell et al., 1999). Therefore, marked morphological changes in the human brain, including sexual differentiation, may not be limited to childhood but may extend into adulthood.

There are several possible explanations for the lack of a sex difference in the BSTc volume shortly after fetal or neonatal sex differences in testosterone levels emerge. Organizational effects of testosterone on sexual differentiation may become clear much later in life. An example of a long delay in organizational effects of gonadal steroids is the development of the sexually dimorphic anteroventral periventricular nucleus (AVPv) in the rat brain, which is larger in females than in males. Although, perinatal sex differences in testosterone cause this sex difference in AVPv size, its volume becomes only significantly different at approximately puberty (Davis et al., 1996). Alternatively, it is possible that sex differences in peripubertal or adult gonadal steroid levels establish the sex difference in BSTc volume in adulthood. Although androgens and estrogens in puberty cause the development of secondary sexual characteristics in peripheral body structures, as far as we know, no data exist on similar effects on human brain structures. However, data from six cases reported in previous studies suggest that the BSTc volume, as delineated by VIP or somatostatin immunocytochemical staining, is not affected by marked increases or decreases in gonadal steroid levels in adulthood. A normal female-sized BSTc was found in one control female with increased androgen levels and in two postmenopausal control females with low gonadal steroid levels. Furthermore, a normal male-sized BSTc was found in a control male with high 
estrogen levels caused by a feminizing adrenal tumor and in two control males who were orchidectomized as a result of prostate cancer. The possibility that gonadal steroid-dependent changes in VIP or somatostatin neuropeptide expression underlie the changes BSTc volume, such as, in quail preoptic area, rat medial amygdala and human amygdala (Panzica et al., 1987; Giedd et al., 1996; Cooke et al., 1999), is also not supported by these six cases who had marked changes in gonadal steroid levels, although their the BSTc volume was normal for their gender (Zhou et al., 1995; Kruijver et al. 2000).

In addition to direct actions of gonadal steroids on the BSTc, the late emergence of sex differences in BSTc volume may reflect relatively late sex-dependent changes in brain areas that supply the BST with its VIP-IR innervation, such as the amygdala (Eiden et al., 1985), which increases in size at a higher rate in males than in females between 4 and 18 years of age (Giedd et al., 1996). Although sex differences in gonadal steroids are the most likely factor to cause sexual differentiation of the BSTc and the areas that innervate the BSTc, we cannot exclude gonadal steroidindependent mechanisms on brain sexual differentiation, such as local expression of sex chromosomal genes (Reisert and Pilgrim, 1991). A candidate gene for such an effect is the $S R Y$ gene, which was shown to be transcribed in the adult human hypothalamus and cortex of males but not in females (Mayer et al., 1998).

Late sexual differentiation of the human BSTc volume also affects our perception about the relationship between BSTs volume and transsexuality. Interestingly, transsexuals receive their first consultation between the ages of 20 and 45 years, which coincides with the period of sex-dependent divergence of BSTc volume found in the present study (Van Kesteren et al., 1996). However, epidemiological studies show that the awareness of gender problems is generally present much earlier. Indeed, 67$78 \%$ of transsexuals in adulthood report having strong feelings of being born in the wrong body from childhood onward (Van Kesteren et al., 1996), supporting the idea that disturbances in fetal or neonatal gonadal steroid levels underlie the development of transsexuality. Moreover, observations that phenobarbital or diphantoin usage during pregnancy, which affect gonadal steroid levels, increases the prevalence of transsexuality in the offspring support this idea (Dessens et al., 1999). Also, girls who had been exposed to high androgen levels as infants caused by congenital adrenal hyperplasia show an increased incidence of gender problems, which supports early developmental programming of this disorder (Meyer-Bahlburg et al., 1996; Zucker et al., 1996). The lack of marked sexual differentiation of the BSTc volume in our study before birth and in childhood certainly does not rule out early gonadal steroid effects on BSTc functions. As suggested by animal experiments, fetal or neonatal testosterone levels in humans may first affect synaptic density, neuronal activity, or neurochemical content during early BSTc development (Döhler, 1991; Park et al., 1997). Changes in these parameters could affect the development of gender identity but not immediately result in overt changes in the volume or neuronal number of the BSTc. Alternatively, it must also be taken into consideration that changes in BSTc volume in male-to-female transsexuals may be the result of a failure to develop a male-like gender identity. In summary, our finding of a sex difference in BSTc volume only in adulthood suggests that marked sex-dependent organizational changes in brain structure are not limited to early development but may extend into adulthood.

\section{REFERENCES}

Abramovich DR, Rowe P (1973) Foetal plasma testosterone levels at mid-pregnancy and at term: relationship to foetal sex. J Endocrinol 56:621-622.

Allen LS, Gorski RA (1990) Sex difference in the bed nucleus of the stria terminalis of the human brain. J Comp Neurol 302:697-706.

Allen LS, Hines M, Shryne JE, Gorski RA (1989) Two sexually dimorphic cell groups in the human brain. J Neurosci 9:497-506.

Braendgaard H, Gundersen HJG (1986) The impact of recent stereologicaladvances on quantitative studies of the nervous system. J Neurosci Methods 18:39-78.

Byne W, Lasco MS, Kemether E, Shinwari A, Edgar MA, Morgello S, Jones LB, Tobet S (2000) The interstitial nuclei of the human anterior hypothalamus: an investigation of sexual variation in volume and cell size, number and density. Brain Res 856:254-258.

Cammermeyer J (1967). Artifactual displacement of neuronal nucleoli in paraffin sections. J Hirnforsch 9:209-224.

Chung WCJ, Swaab DF, De Vries GJ (2000) Apoptosis during sexual differentiation of the bed nucleus of the stria terminalis in the rat brain. J Neurobiol 43:234-243.

Cooke BM, Hegstrom CD, Villeneuve LS, Breedlove SM (1998) Sexual differentiation of the vertebrate brain: principles and mechanisms. Front Neuroendocrinol 19:323-362.

Cooke BM, Tabibnia G, Breedlove SM (1999) A brain sexual dimorphism controlled by adult circulating androgens. Proc Natl Acad Sci USA 96:7538-7540.

Davis EC, Shryne JE, Gorski RA (1996) Structural sexual dimorphisms in the anteroventral periventricular nucleus of the rat hypothalamus are sensitive to gonadal steroids perinatally, but develop peripubertally. Neuroendocrinology 63:142-148.

Del Abril A, Segovia S, Guillamon A (1987) The bed nucleus of the stria terminalis in the rat: regional sex differences controlled by gonadal steroids early after birth. Dev Brain Res 32:295-300.

Dessens AB, Cohen-Kettenis PT, Mellenbergh GJ, Poll N, Koppe JG, Boer K (1999) Prenatal exposure to anticonvulsants and psychosexual development. Arch Sex Behav 28:31-44.

Döhler KD (1991) The pre- and postnatal influence of hormones and neurotransmitters on sexual differentiation of the mammalian hypothalamus. Int Rev Cytol 131:1-57.

Eiden LE, Hökfelt T, Brownstein MJ, Palkovits M (1985) Vasoactive intestinal polypeptide afferents to the bed nucleus of the stria terminalis in the rat: an immunohistochemical and biochemical study. Neuroscience 15:999-1013.

Eriksson PS, Perfilieva E, Bjork-Eriksson T, Alborn AM, Nordborg C, Peterson DA, Gage FH (1998) Neurogenesis in the adult human hippocampus. Nat Med 4:1313-1317.

Giedd JN, Vaituzis AC, Hamburger SD, Lange N, Rajapakse JC, Kaysen D, Vauss YC, Rapoport JL (1996) Quantitative MRI of the temporal lobe, amygdala, and hippocampus in normal human development: ages 4-18 years. J Comp Neurol 366:223-230.

Gould E, Reeves AJ, Graziano MS, Gross CG (1999) Neurogenesis in the neocortex of adult primates. Science 286:548-552.

Guillamon A, Segovia S, Del Abril A (1988) Early effects of gonadal steroids on the neuron number in the medial posterior region and the lateral division of the bed nucleus of the stria terminalis in the rat. Dev Brain Res 44:281-290.

Gundersen HJ, Bagger P, Bendtsen TF, Evans SM, Korbo L, Marcussen N, Moller A, Nielsen K, Nyengaard JR, Pakkenberg B, Sorensen FB, Vesterby A, West MJ (1988) The new stereological tools: disector, fractionator, nucleator and point sampled intercepts and their use in pathological research and diagnosis. APMIS 96:857-881.

Gur RC, Turetsky BI, Matsui M, Yan M, Bilker W, Hughett P, Gur RE (1999) Sex differences in brain gray and white matter in healthy young adults: correlations with cognitive performance. J Neurosci 19:4065-4072.

Jones RL (1937) Split nucleoli as a source of error in nerve cell counts. Stain Technol 12:91-95.

Köningsmark BW (1970) Methods for counting neurons. In: Contemporary research methods in neuroanatomy (Nauta WJH, Ebbesson SOE, eds), pp 315-388. Heidelberg: Springer.

Kruijver FPM, Zhou JN, Pool CW, Hofman MA, Gooren LJG, Swaab DF (2000) Male-to-female transsexuals have female neuron numbers in a limbic nucleus. J Clin Endocrinol Metab 85:2034-2041.

LeVay S (1991) A difference in hypothalamic structure between heterosexual and homosexual men. Science 253:1034-1037.

Mayer A, Lahr G, Swaab DF, Pilgrim C, Reisert I (1998) The Y-chromosomal genes SRY and ZFY are transcribed in adult human brain. Neurogenetics 1:281-288.

Meyer-Bahlburg HF, Gruen RS, New MI, Bell JJ, Morishima A, Shimshi M, Bueno Y, Vargas I, Baker SW (1996) Gender change from female to male in classical congenital adrenal hyperplasia. Horm Behav 30:319-332.

Panzica GC, Viglietti-Panzica C, Calacagni M, Anselmetti GC, Schumacher M, Balthazart J (1987) Sexual differentiation and hormonal con- 
trol of the sexually dimorphic medial preoptic nucleus in the quail. Brain Res 416:59-68.

Park JJ, Baum MJ, Tobet SA (1997) Sex difference and steroidal stimulation of galanin immunoreactivity in the ferret's dorsal preoptic area/ anterior hypothalamus. J Comp Neurol 389:277-288.

Reisert I, Pilgrim C (1991) Sexual differentiation of monoaminergic neurons-genetic or epigenetic? Trends Neurosci 14:468-473.

Sowell ER, Thompson PM, Holmes CJ, Jernigan TL, Toga AW (1999) In vivo evidence for post-adolescent brain maturation in frontal and striatal regions. Nat Neurosci 2:859-861.

Swaab DF, Fliers E (1985) A sexually dimorphic nucleus in the human brain. Science 228:1112-1115.

Swaab DF, Hofman MA (1988) Sexual differentiation of the human hypothalamus: ontogeny of the sexually dimorphic nucleus of the preoptic area. Dev Brain Res 44:314-318.

Swaab DF, Hofman MA (1995) Sexual differentiation of the human hypothalamus in relation to gender and sexual orientation. Trends Neurosci 18:264-270.

Swaab DF, Zhou JN, Ehlhart T, Hofman MA (1994) Development of vasoactive intestinal polypeptide neurons in the human suprachiasmatic nucleus in relation to birth and sex. Dev Brain Res 79:249-259.

Van Eerdenburg FJ, Swaab DF (1994) Postnatal development and sexual differentiation of pig hypothalamic nuclei. Psychoneuroendocrinology 19:471-484.

Van Kesteren PJ, Gooren LJG, Megens JA (1996) An epidemiological and demographic study of transsexuals in The Netherlands. Arch Sex Behav 25:589-600.

Walter A, Mai JK, Lanta L, Gorcs T (1991) Differential distribution of immunohistochemical markers in the bed nucleus of the stria terminalis in the human brain. J Chem Neuroanat 4:281-298.

Winter JSD (1978) Prepubertal and pubertal endocrinology. In: Human growth, Vol 2 (Falkner F, Tanner TM, eds), pp 183-213. New York: Plenum.

Zhou JN, Hofman MA, Gooren LJG, Swaab DF (1995) A sex difference in the human brain and its relation to transsexuality. Nature 378:68-70.

Zucker KJ, Bradley SJ, Oliver G, Blake J, Fleming S, Hood J (1996) Psychosexual development of women with congenital adrenal hyperplasia. Horm Behav 30:300-318. 